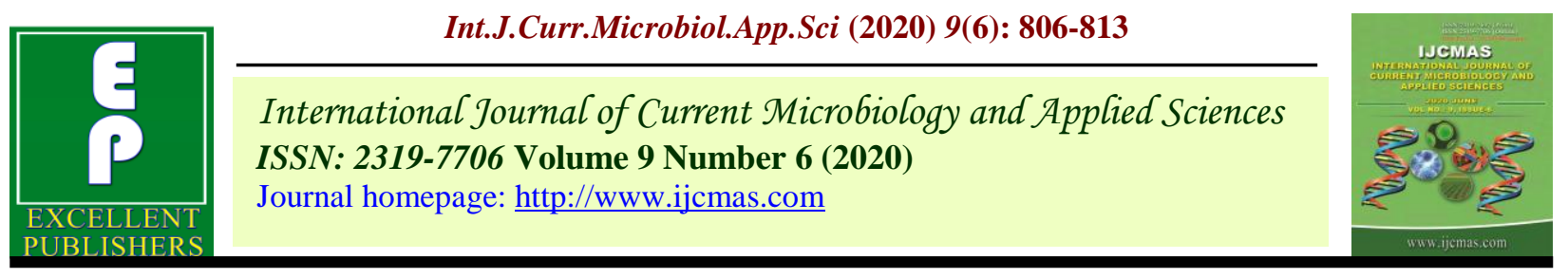

Case Study

https://doi.org/10.20546/ijcmas.2020.906.103

\title{
Efficacy of Tiflicon Spray in Ectoparacitic Infestations in Dogs
}

\author{
G. U. Yadav*, D. U. Lokhande and H. Y. Palampalle \\ Mumbai Veterinary College, Parel, Mumbai-400012, India \\ *Corresponding author
}

\section{A B S T R A C T}

\begin{tabular}{|l|}
\hline Ke y w o r d s \\
Tiflicon, \\
$\begin{array}{l}\text { Ectoparacitic } \\
\text { infestations, } \\
\text { Quantitative } \\
\text { analysis }\end{array}$ \\
\hline Article Info \\
\hline $\begin{array}{l}\text { Accepted: } \\
18 \text { May } 2020 \\
\text { Available Online: } \\
\text { 10 June } 2020\end{array}$ \\
\hline \hline
\end{tabular}

Twenty clinical surgical cases of dogs suffering from ectoparasites and mites presented to Department of Surgery and Radiology, TVCC and The Bai Sakarbai Dinshaw Petit Hospital affiliated to Mumbai Veterinary College Parel, Mumbai were selected for the present study. The treatment of clinical surgical cases of dogs was done with Tifliconspray. Clinical signs like itching, pain, erythema, swelling were subsided 5 days after treatment. The tests like Quantative analysis: ectoparasite visual load at ear, neck, paws and severity of ectoparasites reduced significantly 5 days after treatment with Tiflicon Spray. The mite infestation present in two cases was completely absent on $10^{\text {th }}$ post-treatment day. The ectoparasiticidal action and recovery was good in all the cases treated with Tiflicon Spray.

\section{Introduction}

Ectoparasitic infestations are most common in animals. TifliCon Ectoparasitcide Spray have acaricidal and larvicidal activity which helps in elimination of ticks and mites infestation in pets. The Constituents of TifliCon Ectoparasitcide Spray have anti-inflammatory and wound healing activity, they act through inhibition of pro-inflammatory mediators and strengthening the process of repair. Constituents of TifliCon Ectoparasitcide spray have insecticidal activity in low concentration which helps in the prevention of infestation with lice and fleas. It is used in
Sarcoptic and Demodectic Mange, Mites, Fleas, Ticks, Lice, Dandruff.

To keep the body and hair coat clean and glossy. Sharma et al., (1997) suggested that in view of toxic effects, developing resistance, high cost and the health hazards to humans using these chemical acaricides, use of herbal preparations against skin problems like mange is visualized. Tiflicon spray contains Devdaru/ Cetrus deodara, Cheer/ Pinus longifolia, Lemon grass/ Cymbopogon citratus and Neem/Azadirochita indica and Acorus calamus. Azima et al., (2011) reported the antiparasitic activity of Cymbopogon 
citratus and Azadirochita indica in house dust mites. Present study deals with the study on efficacy of Tiflicon spray in ectoparasitic infections in dogs. [TifliCon Spray-Indian Herbs Specialities Pvt. Ltd. Saharanpur].

\section{Materials and Methods}

Twenty clinical surgical cases of dogs suffering from Ectoparasites and mites presented to Department of Surgery and Radiology, TVCC and The Bai Sakarbai Dinshaw Petit Hospital affiliated to Mumbai Veterinary College Parel, Mumbai were selected for the present study. Clinical signs of different clinical surgical cases of ectoparasitic infestation like itching, pain, erythema, swellings before and 7 days after treatment were studied. The tests like Quantative analysis: ectoparasite load at. ear, neck, paws. Visual load of ticks (live and dead) before and 7 days after treatment skin scrapings to rule out mite infestation before and 10 days after treatment was performed.

The treatment of clinical surgical cases of dogs was done with Tiflicon spray and efficacy against ectoparasites like Fleas, Ticks, Lice, and Mites was studied. Recovery on the basis of clinical signs and skin culture $\&$ sensitivity tests was assessed.

\section{Results and Discussion}

Twenty clinical surgical cases of dogs showing tick infestation and various other surgical conditions were selected for the study. The Tiflicon spray was sprayed once daily for the period of 10 days on the body of dogs and areas where the tick population and density is more.

\section{Itching}

Itching was present in all the $20(100 \%)$ cases suffering from tick infestation before treatment. In 18 (90\%) cases of dogs itching disappeared after 5 days of treatment. This is indicative of effectiveness of Tiflicon spray for subsiding clinical signs of itching due to tick infestations. This may be due to antiinflammatory activity of Tiflicon spray. Constituents of TifliCon Ectoparasitcide Spray like Devdaru/ Cetrus deodara, Cheer/ Pinus longifolia, Lemon grass/ Cymbopogon citratus and Neem/ Azadirochita indica and Acorus calamus have antiparasitic activity. This might be due to presence of Acorus calamus in Tiflicon spray. Mohmad and Hameed (2018) reported that antiinflammatory and antilarvicidal property of Acorus calamus Kim et al., (2009), Kim et al., (2011) and Kim et al., (2012).

\section{Pain}

Out of 20 cases of dogs, pain due to tick infestation was present in $13(65 \%)$ cases before treatment. It completely subsided on $5^{\text {th }}$ and $10^{\text {th }}$ day of treatment. This suggests that Tiflicon spray for reliving clinical signs of pain due to tick bite infestations. Constituents of TifliCon Ectoparasitcide Spray have anti-inflammatory and wound healing activity, they act through inhibition of pro-inflammatory mediators and strengthening the process of repair. This may be due to effect of Acorus calamus, the larvicidal, tranquilizing and antiinflammatory effects of it Mohammad and Hameed (2018).

\section{Erythema}

Out of 20 cases erythema was present in 14 (70\%) cases. The signs of Erythema were completely subsided in all $20(100 \%)$ cases on $5^{\text {th }}$ and $10^{\text {th }}$ day of treatment with Tiflicon Spray. It shows that Tiflicon spray can be effectively used for subsiding clinical signs of erythema caused by tick infestations due to antiparasitic and anti-inflammatory property of Tiflicon spray. Pharmacologically Acorus calamus was reported to possess 
antimicrobial, anti-allergic and antiinflammatory Kim et al., (2009), Kim et al., (2011), Kim et al., (2012).

\section{Swelling}

The swelling at the site of tick bite was present in 6 cases before treatment with Tiflicon whereas it was completely absent in all $6(100 \%)$ the cases after 5 and 10 days of Tiflicon treatment. This might be due to considerable reduction of tick infestation by Tiflicon spray in tick infestations which ultimately lead to no tick bites to animal and no swellings on body of dogs. Tiflicon spray is having anti-inflammatory and wound healing activity, and its action by inhibition of pro-inflammatory mediators and strengthening the process of repair might have reduced the swelling. .Acorus calamus is a traditional remedy for the inflammation but their biological function in the human skin cells not well characterized. Acorus Calamus has been found to inhibit the expression of polyI: C-induced IL-6 and IL-8 which indicates their inhibitory effect on the expression of the cytokines which were likely to be in association with the suppression of $\mathrm{NF}-\kappa \mathrm{B}$ activation and phosphorylation of IRF3 that shows the Acorus calamus L. may be used as a promising immunomodulatory agent in the inflammatory skin diseases Mohmad and Hameed (2018).

\section{Visual load of ectoparasites}

Visual load of ectoparasites was examined at different specially ear, around neck and paws which are the most common sites for tick infestation. Out of 20 cases of dogs 17 (85\%) cases of dogs were having more visual load of ectoparasitic infestation on ears and $18(90 \%)$ cases of dogs were having more visual load on neck and paws before treatment before treatment with Tiflicon Spray. The visual load of tick infestation on ears was absent in 19
(95\%) cases, on neck it was absent in $17(85 \%)$ cases and visual load of tick infestation on paws was absent in 19 (95\%) cases of dogs on the $5^{\text {th }}$ day after treatment with Tiflicon Spray. This is indicative of good effect of Tiflicon Spray for reducing visual load of ectoparasites in dogs after 5 days of topical treatment. TifliCon Ectoparasitcide Spray have acaricidal and larvicidal activity which helps in elimination of ticks and mites infestation in pets. Tiflicon spray containing Devdaru/ Cetrus deodara, Cheer/Pinus Longifolia, Lemon grass/ Cymbopogon citratus and Neem/Azadirochita indica and Acorus calamus which would have reduced the visual load of ectoparasites.Azimaet.al (2011) recorded the effect of Cymbopogon citratus and Azadirachta indica against house dust mites, Sharma et al., (1997) studied efficacy of Cedrus deodura and Benzyl benzoate in sarcoptic mange in sheep.

\section{Severity of ectoparaites}

Severity of ectoparasites was assessed and it was observed that $14(70 \%)$ cases were having +++ severity of ectoparasites before treatment with Tiflicon spray, 4 (20\%) cases were having ++ severity of ectoparasites load of ectoparasites before treatment with Tiflicon spray and $2(10 \%)$ were having ++++ severity of ectoparasites before treatment with Tiflicon spray. Most common sites for ticks were ear, neck and paws. Out of 20 cases in the present study all $20(100 \%)$ cases were having no visual ticks on the ear, neck, paws after 5 days of treatment with Tiflicon spray. This suggests that Tiflicon spray had excellently decreased the severity of ectoparasites after 5 days of treatment. The ingredients of TifliCon Ectoparasitcide Spray have acaricidal and larvicidal activity which helps in removal of ticks and mites infestation in dogs. Sharma et al., (1996) reported the antiparasitic effects of Citrus deodars and Azadirachta indica and benzyl benzoate in 
sarcoptic mange in sheep. Mohmad and Hameed (2018). Reported the antiparasitic effects of Acarus calamus. Azima et al.,
(2011) studied the effect of Cymbopogon citratus and Azadirachta indica against house dust mites.

Table.1 The cases included in the present study are as follows:

\begin{tabular}{|c|c|c|c|c|c|}
\hline Case No. & Breed & Age & Sex & $\begin{array}{l}\text { Body } \\
\text { Weight }\end{array}$ & Disease \\
\hline 1 & ND & 4 months & Female & $6 \mathrm{kgs}$ & $\begin{array}{l}\text { Maggoted wound and tick } \\
\text { infestation }\end{array}$ \\
\hline 2 & ND & 4 months & Female & $6 \mathrm{kgs}$ & $\begin{array}{l}\text { Aural hematoma and tick } \\
\text { infestation }\end{array}$ \\
\hline 3 & ND & 4 months & Male & $8 \mathrm{kgs}$ & $\begin{array}{l}\text { Wound on back and tick } \\
\text { infestation }\end{array}$ \\
\hline 4 & ND & 3months & Male & $4 \mathrm{kgs}$ & $\begin{array}{l}\text { Wound on paw and tick } \\
\text { infestation }\end{array}$ \\
\hline 5 & ND & 5 years & Male & $12 \mathrm{kgs}$ & $\begin{array}{l}\text { Maggot wound and tick } \\
\text { infestation }\end{array}$ \\
\hline 6 & ND & 2 years & Male & $20.5 \mathrm{kgs}$ & $\begin{array}{l}\text { Aural Hematoma and tick } \\
\text { infestation }\end{array}$ \\
\hline 7 & $\mathrm{Lab}$ & 7 years & Female & $23 \mathrm{kgs}$ & $\begin{array}{l}\text { Maggot wound and tick } \\
\text { infestation }\end{array}$ \\
\hline 8 & $\begin{array}{l}\text { Cocker } \\
\text { Spaniel }\end{array}$ & 4 years & Female & $10.7 \mathrm{kgs}$ & Spaying and tick infestation \\
\hline 9 & ND & 8 years & Male & $20.3 \mathrm{kgs}$ & $\begin{array}{l}\text { Ear wound and tick } \\
\text { infestation }\end{array}$ \\
\hline 10 & ND & 6 years & Male & $20 \mathrm{kgs}$ & Lameness and tick infestation \\
\hline 11 & ND & 2 months & Female & $2 \mathrm{kgs}$ & Wound and tick infestation \\
\hline 12 & ND & 6 years & Male & $25 \mathrm{kgs}$ & Castration and tick infestation \\
\hline 13 & ND & 4 months & Female & $6 \mathrm{kgs}$ & Tick infestation and wound \\
\hline 14 & ND & 4 months & Male & $8 \mathrm{kgs}$ & $\begin{array}{l}\text { Swelling on back and tick } \\
\text { infestation }\end{array}$ \\
\hline 15 & ND & 8 years & Male & $20 \mathrm{kgs}$ & $\begin{array}{l}\text { Lacerated wound and tick } \\
\text { infestation }\end{array}$ \\
\hline 16 & ND & 5 months & Male & $12 \mathrm{kgs}$ & Tick infestation and wound \\
\hline 17 & ND & 4 months & Male & $10 \mathrm{kgs}$ & Limping and tick infestation \\
\hline 18 & ND & 10 years & Male & $12 \mathrm{kgs}$ & $\begin{array}{l}\text { Avulsion of nail and tick } \\
\text { infestation }\end{array}$ \\
\hline 19 & ND & 6 years & Female & $35 \mathrm{kgs}$ & $\begin{array}{l}\text { Tick infestation and maggot } \\
\text { wound }\end{array}$ \\
\hline 20 & ND & 6 months & Female & $10 \mathrm{kgs}$ & Tick infestation and wound \\
\hline
\end{tabular}


Case no.1 Severe Ectoparasitic infestation before treatment with Tiflicon spray

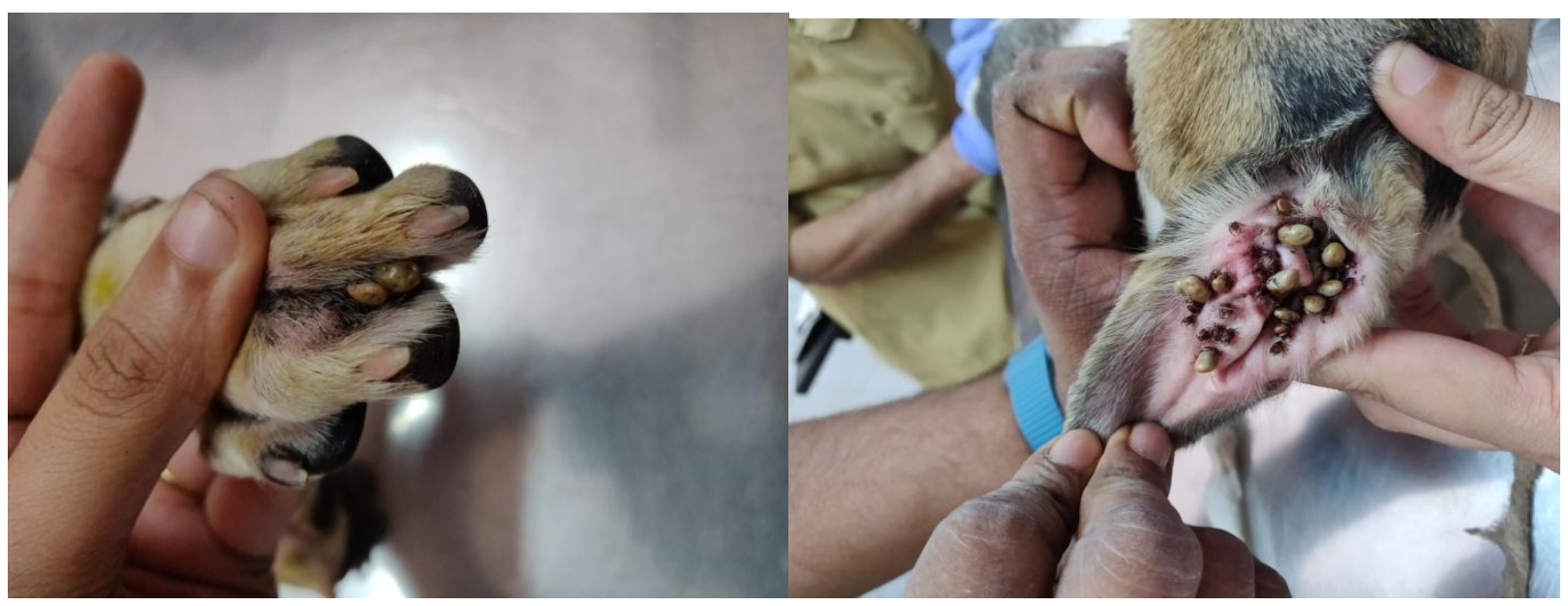

Complete subsidal of ectoparasitic infestation after five days of treatment

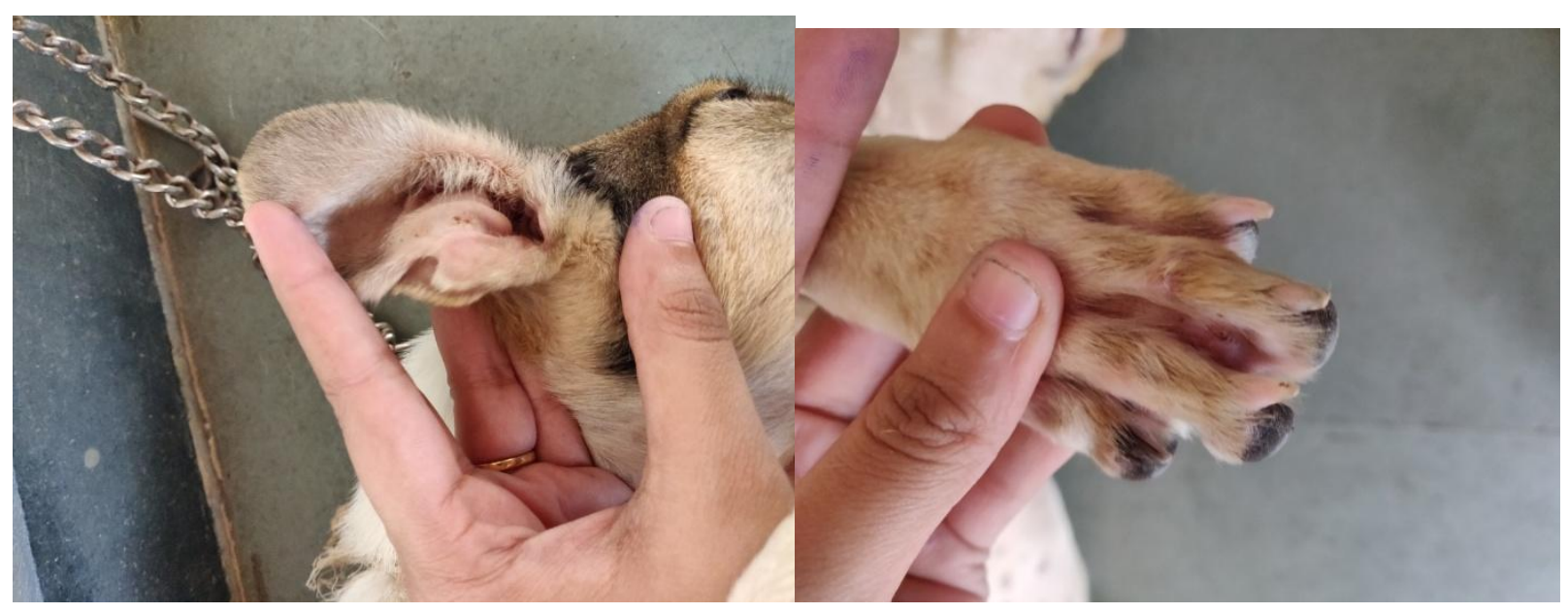

Case no.12 Severe tick infestation before Tiflicon Spray Treatment

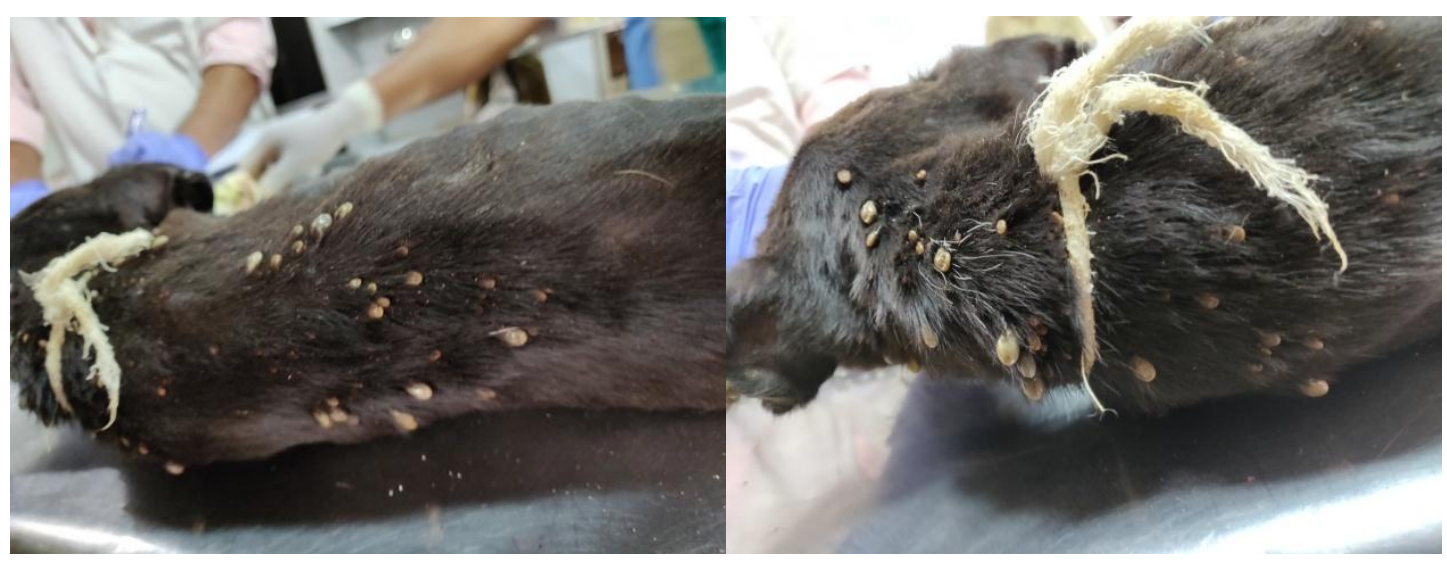


Subsidal of tick infestation after five days after treatment with Tiflicon spray

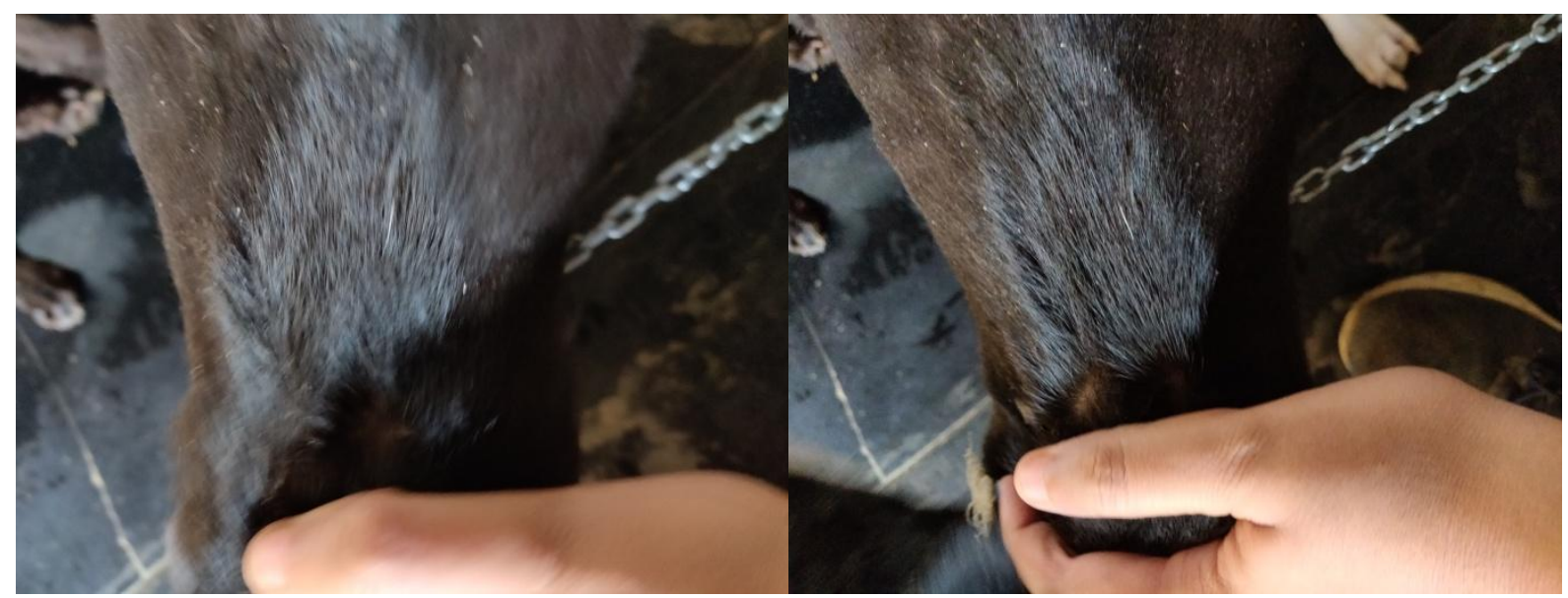

Case no. 19 Severe tick infestation before Tiflicon Spray Treatment

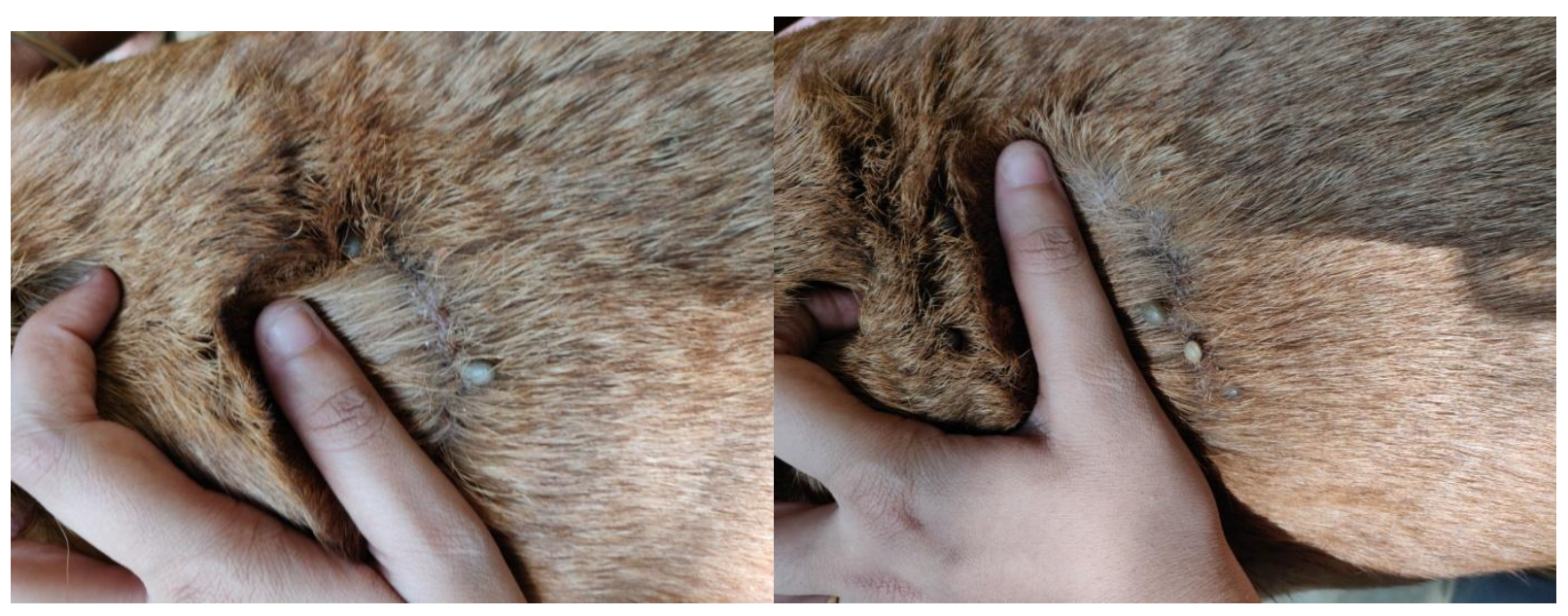

Subsidal of tick infestation after five days after treatment with Tiflicon spray

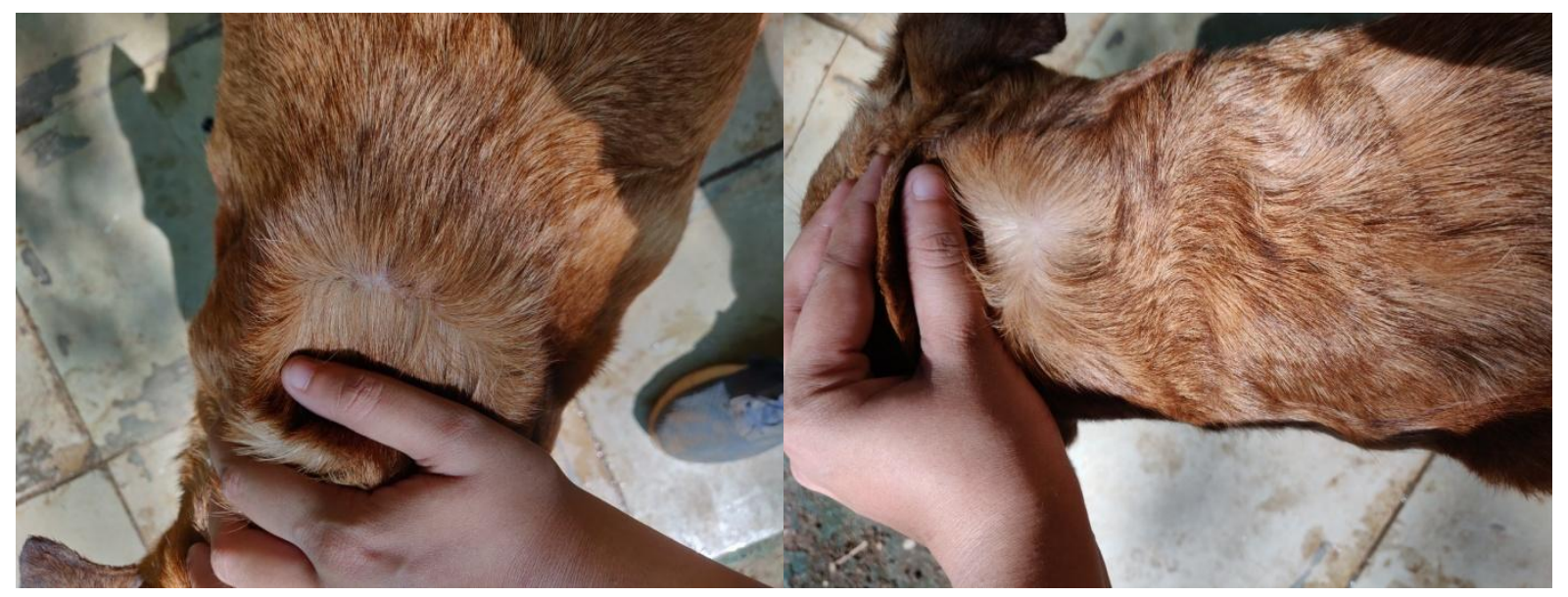




\section{Tests}

\section{Skin scrapping}

The skin scrapping examination was performed to rule out mite infestation before and 10 days after treatment with Tiflicon spray. Out of 20 cases in the present study 2 cases $(10 \%)$ were positive for mite infestation before treatment and the mite infestation was completely absent in all (100\%) cases 10 days after treatment with Tiflicon spray. This shows the good effect of Tiflicon spray in mite infestation also in dogs after 10 days topical treatment on the body. This might be due to anti-parasiticidal action of ingredients of Tiflicon spray Dimri1 and. Sharma ( 2004) reported in sarcoptic mange, Azima et al., (2011) in house dust mites.,

\section{Treatment}

\section{Ectoparacsitidal action}

The Tiflicon spray was sprayed once daily for the period of 10 days on the body where the tick population and density is more.

The ectoparasiticidal action on ticks was considered up-to 10 days of topical application of Tiflicon spray. Out of 20 cases in the present study $12(60 \%)$ cases were having +++ Live dead tick count and $8(40 \%)$ cases were having ++ Live dead ticks on the body of dogs before treatment with Tiflicon spray. In all $20(100 \%)$ dogs the live dead ticks were completely absent on the body 5 days after treatment with Tiflicon spray which may be due to the excellent effect of Tiflicon spray in subsiding live dead tick count and its ectoparasiticidal action. Sharma et al., (1997) Dimri and Sharma (2004), Mohammed and Hameed (2018), Kim et al., (2011), Kim et al., (2012) and Azima et al., (2011) also reported the similar effects of Cetrus deodara, Pinus longifolia, Cymbopogon citratus and
Azadirochita indica and Acorus calamus as antiparasitic and anti-inflammatory.

\section{Recovery}

The recovery on the basis of clinical signs, disappearance of parasites and visual examination and skin scrapings for mites was assessed. The clinical signs like pain, erythema and swelling were completely absent after 5 days of treatment with Tiflicon spray and itching was absent after 5 days of treatment with Tiflicon spray which is suggestive of $90-100 \%$ disappearance of various clinical signs after Tiflicon spray treatment. In majority of cases the parasites on ear, paws and neck completely disappeared after 5 days of Tiflicon treatment. In all the 2 cases (10\%) the skin scrapping was negative for mite infestation after 10 days of treatment with Tiflicon spray. All the above recovery signs indicate that Tiflicon spray can be effectively used for control of tick and mite infestation in dogs. This recovery may be due to the anti-parasitic, anti-inflammatory and tranquilizer property of Tiflicon spray in dogs. Similar findings are reported by Sharma et al., (1997) Dimri and Sharma (2004), Mohammed, and Hameed (2018), Kim et al., (2011), Kim et al., (2012) and Azima et al., (2011) as in the present study.

\section{References}

Azima L.H., SitiH,, A, Ho T. M., Suhaili Z. A., Maizatul H. O. (2011) Asian Pacific Journal of Tropical Biomedicine. 10.1016/S2221-1691(11)60081-6.

Dimri1 U.and. Sharma M. C. (2004) Effects of Sarcoptic Mange and its Control with Oil of Cedrus deodara, Pongamia glabra, Jatropha curcas and Benzyl Benzoate, both with and without Ascorbic Acid on Growing Sheep: Assessment of Weight Gain, Liver Function, Nutrient 
Digestibility, Wool Production and Meat Quality J. Vet. Med. A 51, 79-84.

Ghaidaa J, M, and, Imad H. H. (2018) AntiFungal, Antitumor and AntiInflammatory Activity of Acorus calamus. Indian Journal of Public Health Research \& Development, 9(3): 255-258.

Sharma, D.K., Saxena V.K., Sanil, N.K., Singh, N. (1997). Evaluation of oil of Cedrus deodura and benzyl benzoate in sarcoptic mange in sheep Small Ruminant Research 26 (1997) 81-85.

Kim, H., Han, T.H., Lee, S.G.(2009) Antiinflammatory activity of a water extract of Acorus calamus L. leaves on keratinocyte $\mathrm{HaCaT}$ cells. Journal of Ethnopharmacology 122, 149-156.
Kim, W.J., Hwang, K.H., Park, D.G., Kim, T.J., Kim, D.W., Choi, D.G., Moon, W.K., Lee, K.H., (2011) Major constituents and antimicrobial activity of Korean herb Acorus calamus. Natural Product Research 25, 1278-1281

Kima D.Y, Leea S.H., Kima, W.J., Jianga, J., Kimb, M.K., Shinb Y.K., Kimc D.W., Moonc, Sang W.K., Kwond, C., Koppulaa, S,, Kanga, T.B., Leea H.O. (2012). Inhibitory effects of Acorus calamus extracts on mast cell-dependent anaphylactic reactions using mast cell and mouse model. Journal of Ethnopharmacology xxx (2012) xxxxxx.www.elsevier.com/locate/jethphar $\mathrm{m}$

\section{How to cite this article:}

Yadav, G. U., D. U. Lokhande and Palampalle, H. Y. 2020. Efficacy of Tiflicon Spray in Ectoparacitic Infestations in Dogs. Int.J.Curr.Microbiol.App.Sci. 9(06): 806-813. doi: https://doi.org/10.20546/ijcmas.2020.906.103 